\title{
PROFIL LUARAN MATERNAL DAN NEONATAL SERTA IDENTIFIKASI EKSPRESI GEN SFLT-1 PADA PASIEN PREEKLAMPSIA DI KOTA JAMBI
}

\author{
Herlambang $^{1}$, Susan Tarawifa ${ }^{2}$, Rina Nofri Enis ${ }^{2}$, Ahmad Syauqy $^{3}$, Amelia Dwi Fitri ${ }^{4}$ \\ Departemen Obstetri dan Ginekologi Fakultas Kedokteran dan Ilmu Kesehatan Universitas \\ Jambi/RSUD Raden Mattaher Jambi ${ }^{1}$ \\ Departemen Anatomi Fakultas Kedokteran dan Ilmu Kesehatan Universitas Jambi ${ }^{2}$ \\ Departemen Biokimia dan Biomedik Fakultas Kedokteran dan Ilmu Kesehatan Universitas Jambi ${ }^{3}$ \\ Departemen Medical Education Fakultas Kedokteran dan Ilmu Kesehatan Universitas Jambi ${ }^{4}$ \\ herlambang_fkik@unja.ac.id ${ }^{1}$, susantarawifa@unja.ac.id²
}

\begin{abstract}
Preeclampsia is a pregnancy-specific condition characterized by placental dysfunction. The diagnosis of preeclampsia is based on the presence of hypertension and proteinuria at gestational age above 20 weeks. The pathogenesis of preeclampsia is very complex many genes are involved, including SFlt-1 which is secreted by the placenta in a hypoxic state. Other risk factors that influence the incidence of preeclampsia are maternal age and gravida status. Preeclampsia will affect the condition of fetal development, including premature delivery. This study was conducted to determine the profile of maternal and neonatal outcomes and the expression of the SFlt-1 gene in preeclampsia patients in Jambi City. This research is an observational descriptive study using a cross-sectional method.The mRNA was extracted from placental tissue of preeclamptic patients at the time of termination of pregnancy. Gene expression was assessed using real-time PCR. The results obtained from the maternal age profile in preeclampsia patients showed that there were more mothers with high-risk age (52\%) and primigravida (56\%) who had preeclampsia and the neonatal outcome was found to be low birth weight babies (28\%) and the expression of the sFlt-1 gene was $\Delta \Delta \mathrm{cq}-2.89$ at birth age, at maternal age -3.27, at 0.80 gravida status. The maternal outcome is higher in mothers with high-risk age, preterm birth, and primigravida in preeclampsia patients. In preeclampsia, the neonatal outcome was LBW. Expression of the sFlt-1 gene is increased in preeclamptic patients.
\end{abstract}

Keywords $\quad$ : Preeclampsia, Preterm birth, sFlt-1

\begin{abstract}
ABSTRAK
Preeklampsia merupakan kondisi spesifik pada kehamilan yang ditandai dengan adanya disfungsi plasenta. Diagnosis preeklampsia ditegakkan berdasarkan adanya hipertensi dan proteinuria pada usia kehamilan diatas 20 minggu. Patogenesis preeklampsia sangat kompleks, banyak gen yang ikut terlibat, diantaranya adalah SFlt-1 yang disekresikan plasenta dalam keadaan hipoksia. Faktor risiko lain juga berpengaruh pada kejadian preeklampsia adalah usia ibu dan status gravida. Preeklampsia akan berefek kepada kondisi perkembangan janin, termasuk persalinan prematuritas. Penelitian ini dilakukan untuk mengetahui profil luaran maternal dan neonatal serta ekspresi gen SFlt-1 pada pasien preeklampsia di Kota Jambi. Penelitian ini merupakan penelitian deskriptif observasional menggunakan metode crossectional. Ekspresi mRNA yang akan dinilai diekstrak dari jaringan plasenta pasien preeklampsia pada saat terminasi kehamilan. ekspresi gen dinilai secara kuantitatif menggunakan realtime PCR. Perolehan hasil profil usia ibu pada pasien preeklampsia didapatkan lebih banyak ibu dengan usia berisiko tinggi $(52 \%)$ dan primigravida $(56 \%)$ yang mengalami preeklampsia dan luaran neonatal didapatkan bayi dengan BBLR (28\%) serta ekspresi gen sFlt-1 didapatkan $\Delta \Delta$ cq -2.89 pada usia kelahiran, pada usia ibu -3.27 , pada status gravida 0.80 . Profil usia ibu lebih banyak ibu dengan usia risiko tinggi, kelahiran preterm dan primigravida pada pasien preeklampsia. Pada preeklampsia didapatkan luaran neonatal yaitu BBLR. Ekspresi gen sFlt-1 meningkat pada pasien preeklampsia.
\end{abstract}

Kata Kunci : Preeklampsia, Preterm, Sflt-1 


\section{PENDAHULUAN}

Preeklampsia (PE) adalah suatu gangguan yang bersifat sistemik pada kehamilan. Kondisi patologis ini dapat menyebabkan komplikasi pada persalinan mencapai lebih dari 3-6\% di negara maju. Gejala yang menandai kondisi PE yaitu dijumpai hipertensi dan disertai dengan adanya proteinuria pada ibu hamil yang sebelum kehamilan memiliki tekanan darah normal (Wang, Diniz, 2020). Sindroma ini baru bias dikategorikan sebagai PE apabila muncul pada usia kehamilan diatas 20 minggu kehamilan. Terapi definitive untuk PE adalah terminasi kehamilan karena gejala akan berkurang atau menghilang setelah pasien melahirkan. Kondisi PE apabila dibiarkan tanpa penanganan yang adekuat dapat mengakibatkan morbiditas dan mortalitas meningkat baik pada ibu maupun janin (Diniz, 2020).

Dari Rakernas 2019 dinyatakan bahwa sekitar $75 \%$ etiologi mortalitas ibu hamil disebabkan perdarahan post- partum, preeklampsia / eklampsia, infeksi pasca persalinan, dan penyebab lainnya, sedangkan pada kematian neonatal penyebab utama tersering antara lain kelahiran prematur, asfiksia, infeksi, dan cacat lahir (Achadi, 2019).

Patogenesis preeklampsia sangat kompleks, dipengaruhi oleh genetik, imunologi, dan interaksi faktor lingkungan. (Pribadi, 2015) Pada preeklampsia terjadi invasi sitotrofoblas secara abnormal ke miometrium yang menyebabkan kegagalan proses remodelling arteri spiralis. Vasa ini tetap mempunyai dinding muskuloelastik sehingga terjadi vasospasme dan penyumbatan pada miometrium. Hal tersebut dapat menyebabkan lumen arteri spiralis menyempit dan terbatasnya suplai darah dari ibu melalui plasenta menuju ke janin. Apabila kondisi ini berlangsung terus seiring dengan pertambahan usia kehamilan akan menyebabkan hipoperfusi. Uterus tidak mendapat suplai kebutuhan oksigen dan nutrisi bagi perkembangan janin secara adekuat. Lama kelamaan akan terjadi suatu keadaan iskemia plasenta, sebagai hasil dari hipoksia yang berlarut-larut (Spradley, 2016).

Plasenta yang mengalami hipoksia menghasilkan protein antiangiogenik yaitu sFLT-1. Didalam sirkurlasi sFlt-1 berikatan dnegan vascular endothelial growth factor (VEGF) and the placental growth factor (PLGF). Ketidakseimbangan antara level sFlt-1 dan VEGF/PLGF diduga memiliki kontribusi terhadap terjadinya hipertensi dan proteinuria (Koga et al, 2010, Bdolah, 2014). Invasi trofoblas yang buruk dalam preeklampsia juga mengganggu remodeling arteri spiralis diikuti dengan plasenta iskemik/reperfusi dan inflamasi (SánchezAranguren, 2014).

Dari studi kasus yang dilakukan oleh Ajeng Galuh, 2012, angka kejadian preeklampsia di jambi masih terbilang cukup tinggi yaitu sekitar $17,7 \%$ dari seluruh ibu hamil yang pernah dirawat di RS Raden Mataher periode 2012. Tingginya insidensi preeklampsia ini dapat disebabkan oleh banyak hal diantaranya adalah status gravida dan usia ibu. Faktor ini yang akan mempengaruhi usia kehamilan saat terminasi dan luaran neonatal berupa berat badan bayi lahir rendah (BBLR) (Wuryandari, 2012). Berdasarkan hal tersebut peneliti tertarik melakukan penelitian yang bertujuan untuk mengetahui profil luaran maternal dan neonatal serta ekspresi gen sFlt-1 yang berperan terhadap patomekanisme preeklampsia pada wanita hamil yang didiagnosa dengan preeklampsia di Kota Jambi.

\section{METODE}

Penelitian ini merupakan penelitian deskriptif observasional, dengam jumlah sampel sebanyak 25 sampel. Pengambilan sampel menggunakan metode purposive sampling, dimana populasi yaitu ibu hamil dan melahirkan di RSUD Raden Mattaher 
Kota Jambi. Kriteria inklusi yaitu wanita hamil yang didiagnosis dengan preeklampsia sesuai dengan kriteria diagnosis preeklampsia menurut American College Obstetricians and Gynecologysts, 2013. ${ }^{10}$ Adapun kritria ekslusi adalah sebagai berikut: wanita hamil < 20 minggu, berkas rekam medik tidak lengkap, menderita hipertensi pada saat usia hamil $<20$ minggu, adanya tanda infeksi akut berdasarkan anamnesis dan pemeriksaan fisik. Data yang diperoleh dianalisis univariat menggunakan SPSS.

Jaringan plasenta sampel sebesar $5 \times 5$ $\mathrm{cm}$ diambil pada saat terminasi, kemudian dilakukan isolasi RNA jaringan plasenta menggunakan SV Total RNA Isolation System Kit dengan protokol sesuai dengan yang dianjurkan. RNA kemudian ditranskripsikan menjadi cDNA dan ekspresi gen dinilai secara realtime PCR menggunakan kit Go-Taq 2 Step qRT-PC sesuai petunjuk yang dianjurkan. Ekspesi gen dinilai secara kuantitatif dengan membandingkan antara ekspresi gen target dan house keeping gene. Primer yang digunakan pada penelitian adalah sebagai berikut:

Tabel 1. Daftar Urutan Basa untuk Primer sFlt-1 dan GAPDH

\begin{tabular}{|c|c|c|}
\hline Gen & Primer Forward & Primer Reverse \\
\hline & 5'- & $5 '-$ \\
\hline \multirow{2}{*}{$\begin{array}{l}\text { sFlt- } \\
1\end{array}$} & CTCCTGCGAAACC & GACGATGGTGACGT \\
\hline & TCAGTG-3' & TGATGT-3' \\
\hline \multirow{3}{*}{$\begin{array}{l}\text { GAP } \\
\text { DH }\end{array}$} & $5 '-$ & $5 '-$ \\
\hline & GCAAATTCCATGG & TCGCTCCTGGAAGA \\
\hline & CACCGT-3' & TGGTGAT-3' \\
\hline
\end{tabular}

\section{HASIL}

Penelitian yang telah dilakukan, didapatkan 25 sampel yang memenuhi kriteria inklusi dan eksklusi pasien preeklampsia. Berdasarkan karakteristik usia ibu sampel akan dibagi menjadi dua kategori, yaitu berisiko tinggi dengan rentang usia dibawah 20 tahun serta diatas 35 tahun, dan berisiko rendah dengan rentang usia antara 20-35 tahun. Didapatkan hasil usia ibu yang berisiko tinggi 13 orang (52\%) dan berisiko rendah 12 orang $(48 \%)$.

Berdasarkan status gravida, sampel akan dibagi menjadi dua katergori, yaitu primigravida dan multigravida, yaitu primigravida adalah ibu yang baru hamil pertama kali, sedangkan multigravida adalah ibu yang telah hamil lebih dari dua kali. Didapatkan hasil status gravida untuk primigravida sebanyak 14 orang $(56 \%)$ dan multigravida sebanyak 11 orang (44\%).

Untuk sampel berdasarkan usia kehamilan saat terminasi akan dibagi menjadi dua kategori, yaitu preterm dimana usia kehamilan antara 22-37 minggu dan aterm dimana usia kehamilan diatas 36 minggu saat kelahiran. Didapatkan hasil untuk usia kehamilan, kehamilan preterm sebanyak 8 orang (32\%) dan aterm sebanyak 17 orang $(68 \%)$.

Untuk sampel berdasarkan berat badan lahir bayi akan dibagi menjadi dua kategori, yaitu BBLR dimana berat bayi $<2500$ gr saat lahir dan Berat bayi lahir normal dengan berat bayi antara $2500 \mathrm{gr}-$ 4000 gr saat lahir. Didapatkan hasil untuk BBLR sebanyak 7 orang (28\%) dan aterm sebanyak 18 orang (72\%). Hasil deskripsi karakteristik dapat dilihat pada tabel 1.

Tabel 2. Distribusi Frekuensi Karakteristik Profil Ibu Pada Preeklampsia.

\begin{tabular}{lcc}
\hline Karakterisik Sampel & $\mathrm{f}$ & $\%$ \\
\hline Usia kehamilan & 8 & 32 \\
$\quad \begin{array}{l}\text { Preterm } \\
\text { Aterm }\end{array}$ & 17 & 68 \\
\hline Status Gravida & & \\
$\quad$ Primigravida & 14 & 56 \\
$\quad$ Multigravida & 11 & 44 \\
\hline Usia Ibu & & \\
$\quad$ Berisiko rendah & 12 & 48 \\
$\quad$ Berisiko tinggi & 13 & 52 \\
\hline Berat Bayi Lahir & & \\
$\quad$ Berat Bayi Lahir Rendah & 7 & 28 \\
$\quad$ Berat Bayi Lahir Normal & 18 & 72 \\
\hline
\end{tabular}

Penghitungan ekspresi gen sFlt-1 dilakukan dengan quantitative RT-PCR 
dengan menilai cycle of amplification $(C q)$ gen tersebut. Kuantitas sequens DNA target didapat dengan menentukan jumlah siklus amplifikasi yang diperlukan untuk menghasilkan produk PCR berdasarkan fluoresensi di awal fase eksponensial serta untuk melewati garis ambang fluoresensi/siklus threshold. Semakin kecil nilai $\mathrm{Cq}$, maka semakin banyak template gen pada sampel. Delta $\mathrm{Ct}(\Delta \mathrm{Cq})$ adalah nilai antara $\mathrm{Cq}$ gen target dan $\mathrm{Cq}$ gen referensi (GAPDH). Nilai rata-rata $\Delta \mathrm{Ct}$ dari setiap kelompok pada penelitian ini dapat dilihat di tabel 3.

Perhitungan ekspresi gen sFLT-1 pada kuantifikasi relatif dapat dilakukan melalui comparative threshold cycle $(\mathrm{Cq})$. Pada metode ini, nilai $\mathrm{Cq}$ dijadikan dasar untuk mengkuantifikasi ekspresi gen sFLT-1 secara relatif terhadap Cq GAPDH. Delta $\mathrm{Cq}(\Delta \mathrm{Cq})$ adalah nilai antara $\mathrm{Cq}$ gen target dan $\mathrm{Cq}$ gen referensi.

\section{Tabel 3. Hasil RT PCR}

\begin{tabular}{lcc}
\hline \multicolumn{1}{c}{ Karakteristik } & $\Delta \mathrm{Cq}$ & $\Delta \Delta \mathrm{Cq}$ \\
\hline Usia Kehamilan & & \\
\hline Preterm & $-2,86$ & $-2,89$ \\
Aterm & 0,03 & \\
\hline Usia Ibu & & \\
\hline Resiko tinggi & $-0,89$ & $-3,27$ \\
Tidak resiko tinggi & 2,38 & \\
Status Gravidarum & & \\
Primigravida & 0,79 & 0,32 \\
Multigravida & 0,47 & \\
\hline
\end{tabular}

\section{PEMBAHASAN}

Penelitian ini bertujuan untuk mengetahui profil luaran maternal dan neonatal serta mengidentifikasi ekspresi gen sFlt-1 pada pasien preeklampsia, dikarenakan pada kondisi preeklampsia terjadi hipertensi yang tidak hanya membahayakan ibu tetapi juga membahakan janin selama kehamilan (Ukah UV, et al., 2017).

Pada keadaan preeklampsia terjadi kegagalan remodelling arteri spiralis sehingga menimbulkan vasospasme yang mengakibatkan adanya hipoperfusi uteroplasenta. Penurunan perfusi menuju uterus mengakibatkan adanya transfer oksigen dan nutrisi yang tidak adekuat. Apabila kondisi ini tetap berlanjut akan menyebabkan terjadinya Intrauterine Growth Restriction (IUGR) yang memicu bayi lahir prematur, bayi lahir dengan berat badan rendah hingga kematian neonatal (Khosravi S, et al., 2014).

Pada penelitian ini juga didapatkan hasil luaran maternal berupa $32 \%$ ibu dengan preeklampsia mengalami persalinan preterm atau proses kelahiran lebih cepat dari waktu seharusnya. Hasil ini juga sesuai dengan penelitian yang dilakukan oleh Widya dan Syarif (2016) menyebutkan penyebab utama kematian perinatal di Indonesia adalah kelahiran prematur dengan angka kejadian prematur dengan kematian perinatal sekitar 19\% (Sari \& Syarif., 2016). Hal ini juga dapat terlihat pada hasil penelitian ini yang mendapatkan luaran neonatal berupa berat lahir bayi yang rendah (BBLR) sebanyak 28\%, dimana kondisi bayi yang lahir dengan berat badan rendah merupakan salah satu faktor yang meyebabkan timbulnya kematian bayi (Patel RM, et al., 2015).

Menurut International Society of Hypertension Global Hypertension Practice Guidelines, hipertensi dalam kehamilan mempengaruhi $5 \% \quad-10 \%$ kehamilan di seluruh dunia. Hasil analisis menyebutkan bahwa ibu berisiko melahirkan bayi prematur sebanyak 3-4 kali apabila mengalami hipertensi dalam kehamilan dibandingkan ibu dengan kehamilan normal (Sunderji, et al., 2010). Begitu juga dengan penelitian yang dilakukan oleh Zhang et al yang menyebutkan bahwa komplikasi kehamilan dengan penyulit berupa preeklampsia memberikan risiko lebih besar yaitu sebesar 3-4 kali untuk terjadinya kelahiran prematur dibandingkan yang kehamilan normal (Zhang, et al., 2019).

Terkait luaran maternal berdasarkan usia ibu dan status gravida, pada penelitian ini didapatkan ibu yang memiliki usia berisiko tinggi yaitu dibawah 20 tahun dan 
diatas 35 tahun lebih banyak yang mengalami preeklampsia dibandingan dengan ibu berusia risiko rendah yaitu dengan rentang usia antara 20 - 35 tahun. Kondisi ini dapat dijelaskan karena umur merupakan salah satu faktor yang menentukan status kesehatan ibu hamil. Akan tetapi pada kasus preklampsia umur tidak menjadi satu-satunya faktor resiko kemunculan preeklampsia, melainkan ada faktor lain seperti status gravida yaitu primigravida, obesitas, kehamilan ganda gangguan metabolik lain selama kehamilan, kondisi sosial ekonomi, dan lainnya (Cunningham, 2010).

Usia ibu berkaitan erat dengan sistem kekebalan tubuh, fungsi sel, serta berkaitan dengan kemampuan ibu dalam memberikan nutrisi dan oksigenasi kepada janin yang dikandung. Sebagian masalah kesehatan adalah berkaitan dengan usia. Tekanan darah tinggi dan beberapa bentuk diabetes berkaitan dengan usia. Pada usia $>35$ tahun juga seorang wanita mempunyai kesempatan 5\% melahirkan bayi dengan kelainan kromosom. Usia resiko tinggi juga berkaitan dengan Fungsi sel dan sistem tubuh pada ibu pada rentang usia beresiko berbeda dengan ibu pada usia sehat (Khusen, 2012).

Proses plasentasi dapat berjalan dengan normal sejak awal kehamilan dipengaruhi oleh kemampuan sel untuk melakukan remodelling pada awal kehamilan. Proses ini sangat penting agar janin mendapat suplai oksigen secara cukup. Pada kehamilan akan memicu terjadinya peningkatan metabolisme guna mencukupi kebutuhan oksegen dan nutrisi baik untuk ibu maupun janin. Apabila arteri spiralis tidak dapat mengakomodasi peningkatan aliran darah yang diperlukan, maka akan menimbulkan disfungsi plasenta yang bermanifestasi klinis sebagai preeklampsia. Terdapat hubungan umpan balik positif antara plasentasi abnormal dan hipoperfusi plasenta hingga hipoksia (Putra, dkk., 2014).

Soluble Vascular Endothelial Growth Factor Reseptor-1 (sFlt-1) juga dikenal dengan (sVEGFR-1), adalah variasi bentuk dari reseptor Flt-1. Reseptor Flt-1 diekspresikan pada beberapa jaringan, antara lain trofoblas plasenta dan monosit/makrofag. Reseptor ini mengikat VEGF-A, VEGF-B dan PLGF dengan kuat.(Bdolah, 2014) Patogenesis preeklampsia memiliki hubungan dengan ekspresi maupun sekresi sFLT-1 pada sirkulasi maternal. Disfungsi endotel pada kondisi preeklampsia berkaitan dengan peningkatan sFLT-1 pada serum ibu hamil, yang ditandai dengan timbulnya manifestasi klinis. (Lam, et al., 2015)

Pada penelitian ini dilakukan penilaian sFlt-1 pada setiap karakteristik. Hasil yang didapatkan pada karakteristik usia kehamilan saat terminasi adalah hasil $\Delta \mathrm{Cq}$ pasien preeklampsia dengan usia kehamilan preterm lebih kecil $(-2,86)$ daripada usia aterm $(0,03)$. Hal ini menandakan bahwa ekspresi sFlt-1 pada kelompok preterm lebih tinggi dibandingkan ibu dengan usia kehamilan aterm.

Pada preeklampsia terjadi iskemia plasenta, sehingga plasenta melepaskan berbagai macam plasental faktor termasuk protein angiogenik sFlt-1 yang justru menimbulkan respon inflasmasi dan mempengaruhi endotel maternal sehingga menyebabkan gangguan sistemik ibu dan gangguan sirkulasi uteromaternal serta penurunan perfusi darah ibu ke janin (Sunderji, et al., 2010)

Proses inflamasi ini menyebabkan ibu untuk melakukan dekompensasi, terjadi peningkatan produksi kortisol dan dan sitokin yang lebih besar. Hal ini diasosiasikan dengan meningkatnya risiko kelahiran bayi prematur (Sun L-J, et al., 2018). Hasil penelitian ini juga menunjukkan bahwa usia ibu dengan resiko tinggi yaitu usia $<20$ tahun atau $>35$ tahun memiliki ekspresi sFlt-1 lebih tinggi $(\Delta \mathrm{Cq}$ : $-0,89)$ dibandingkan dengan usia ibu resiko rendah $(\Delta \mathrm{Cq}: 0,03)$.

Organ reproduksi wanita dengan usia $<20$ tahun belum siap untuk terjadinya suatu proses kehamilan sehingga beresiko untuk mengalami kelainan plasentasi. 
Begitupula dengan usia di atas 35 tahun, dimana mulai terjadinya proses degeneratif yang juga akan mengganggu proses implantasi dan perkembangan trofoblas. Invasi trofoblas yang buruk akan mengganggu remodeling arteri spiralis diikuti dengan plasenta iskemik/reperfusi dan inflamasi yang merupakan salah satu patogenesis preeklampsia (Shao Y, et al., 2017).

Salah satu faktor resiko lain kejadian preeklampsia adalah status gravidarum primigravida (Khuzaiyah, Anies, 2016). Pada penelitian ini hasil $\Delta \mathrm{Cq}$ sFlt-1 pada primigravida tidak begitu berbeda dengan multigravida yaitu 0,79 pada primigravida dan 0,47 pada multigravida. Hal ini menandakan bahwa ekspresi sFlt-1 pada primigravida tidak jauh lebih besar dibandingkan dengan multigravida.

\section{KESIMPULAN}

Profil luaran maternal didapatkan lebih banyak ibu dengan usia risiko tinggi dan primigravida dan juga didapatkan kelahiran prematur pada pasien preeklampsia. Pada preeklampsia didapatkan luaran neonatal yaitu BBLR. Ekspresi gen sFlt-1 meningkat pada pasien preeklampsia.

\section{UCAPAN TERIMAKASIH}

Penelitian ini dilaksanakan dengan skema dana penelitian Fakultas Kedokteran dan Ilmu Kesehatan (FKIK) Universitas Jambi (UNJA). Untuk itu peneliti mengucapkan terima kasih kepada Dekan Fakultas Kedokteran dan Ilmu Kesehatan Universitas Jambi, serta berkat dukungan dari dosen FKIK yang lain, peneliti dan tim penelitian dapat menyelesaikan penelitian ini. Selain itu bantuan dan dukungan dari berbagai pihak sehingga tim peneliti dapat melaksanakan penelitian ini dengan baik.

\section{DAFTAR PUSTAKA}

Achadi, E. L. (2019). Kematian maternal dan neonatal di indonesia. FKM UI pada Rakernas.

American College of Obstetricians and Gynecologists. (2013). Hypertension in pregnancy. Report of the American College of Obstetricians and Gynecologists' task force on hypertension in pregnancy. Obstetrics and gynecology, 122(5), 1122-1131.

Bdolah, Y., Elchalal, U., Natanson-Yaron, S., Yechiam, H., Bdolah-Abram, T., Greenfield, C., ... \& HochnerCelnikier, D. (2014). Relationship between nulliparity and preeclampsia may be explained by altered circulating soluble fms-like tyrosine kinase 1. Hypertension in pregnancy, 33(2), 250-259.

Cohen, W. R. (2014). Does maternal age affect pregnancy outcome?.BJOG: An International Journal of Obstetrics \& Gynaecology, 121(3), 252-254.

Cunningham, FG, Lenovo KJ, Bloom SL, Hauth JC, Gilstrap LC, dan Wenstrom KD. (2012). Obstetri Williams, Ed.23, vol.2. EGC, Jakarta

Diniz, A. L. D., Paes, M. M. B. M., \& Diniz, A. D. (2020). Analyzing preeclampsia as the tip of the iceberg represented by women with long-term cardiovascular disease, atherosclerosis, and inflammation. Current atherosclerosis reports, 22(3), 1-8.

Khosravi, S., Dabiran, S., Lotfi, M., \& Asnavandy, M. (2014). Study of the prevalence of hypertension and complications of hypertensive disorders in pregnancy. Open Journal of Preventive Medicine, 4(11), 860.

Khusen, D. (2012). Factors influencing maternal mortality from severe preeclampsia and eclampsia. Indonesian Journal of Obstetrics and Gynecology, 36(2), 90-94.

Khuzaiyah, S., Anies, A., \& Wahyuni, S. (2016). Karakteristik Ibu Hamil 
Preeklampsia. Jurnal

ilmiah

kesehatan, 9(2), 97065.

Koga, K., Osuga, Y., Tajima, T., Hirota, Y., Igarashi, T., Fujii, T., ... \& Taketani, Y. (2010). Elevated serum soluble fms-like tyrosine kinase 1 (sFlt1) level in women with hydatidiform mole. Fertility and sterility, 94(1), 305-308.

Lam, C., Lim, K. H., \& Karumanchi, S. A. (2005). Circulating angiogenic factors in the pathogenesis and prediction of preeclampsia. Hypertension, 46(5), 1077-1085.

Patel, R. M., Kandefer, S., Walsh, M. C., Bell, E. F., Carlo, W. A., Laptook, A. R., ... \& Stoll, B. J. (2015). Causes and timing of death in extremely premature infants from 2000 through 2011. New England Journal of Medicine, 372(4), 331-340.

Pribadi, A., Mose, J. C., \& Anwar, A. D. (2015). Kehamilan risiko tinggi. Jakarta: CV. Sagung Seto

Putra, A. N. E., Hasibuan, S., \& Fitriyati, Y. (2014). Hubungan Persalinan Preterm Pada Preeklampsia Berat Dengan Fetal Outcome Di RSU Islam Harapan Anda Tegal. Jurnal Kedokteran dan Kesehatan Indonesia, 6(3), 113-119.

Sánchez-Aranguren, L. C., Prada, C. E., Riaño-Medina, C. E., \& Lopez, M. (2014). Endothelial dysfunction and preeclampsia: role of oxidative stress. Frontiers in physiology, 5, 372.

Sari, T. W., \& Syarif, S. (2016). Hubungan Prematuritas dengan Kematian Neonatal Tahun 2010. Jurnal Epidemiologi Kesehatan Indonesia, 1(1).

Shao Y, Qiu J, Huang H, Mao B, Dai W, $\mathrm{He} \mathrm{X}$, et al. (2017). Pre-pregnancy $\mathrm{BMI}$, gestational weight gain and risk of preeclampsia: A birth cohort study in Lanzhou, China. BMC Pregnancy Childbirth, 17(1), 1-8.

Spradley, F. T., Tan, A. Y., Joo, W. S., Daniels, G., Kussie, P., Karumanchi,
S. A., \& Granger, J. P. (2016). Placental growth factor administration abolishes placental ischemia-induced hypertension. Hypertension, 67(4), 740-747.

Sun, L. J., Xu, G. F., Lv, M., Zhou, H., Huang, H. F., \& Luo, Q. (2018). Predictive Value of Maternal Serum Biomarkers for Preeclampsia and Birth Weight: A Case-Control Study in Chinese Pregnant Women. Journal of Women's Health, 27(12), 15191524.

Sunderji, S., Gaziano, E., Wothe, D., Rogers, L. C., Sibai, B., Karumanchi, S. A., \& Hodges-Savola, C. (2010). Automated assays for sVEGF R1 and PlGF as an aid in the diagnosis of preterm preeclampsia: a prospective clinical study. American journal of obstetrics and gynecology, 202(1), 40-e1.

Ukah, U. V., Hutcheon, J. A., Payne, B., Haslam, M. D., Vatish, M., Ansermino, J. M., .. \& Von Dadelszen, P. (2017). Placental growth factor as a prognostic tool in women with hypertensive disorders of pregnancy: a systematic review. Hypertension, 70(6), 12281237.

Unger, T., Borghi, C., Charchar, F., Khan, N. A., Poulter, N. R., Prabhakaran, D., ... \& Schutte, A. E. (2020). 2020 International Society of Hypertension global hypertension practice guidelines. Hypertension, 75(6), 1334-1357.

Wang, Y., \& Alexander, J. S. (2000). Placental pathophysiology in Preeclampsia. Pathophysiology, 6 (4), 261-270.

Wuryandari, A. G. (2012). Faktor-faktor Yang Berhubungan Dengan Kejadian Pre-Eklampsia Di RSUD Raden Mattaher Jambi Tahun 2012. Jurnal Penelitian Universitas Jambi Seri Sains, 15(1), 17-26.

Zhang, B. Y., Li, S. S., Shang, S. H., Li, M. M., Li, S. R., Mi, B. B., ... \& Dang, S. 
N. (2019). Interaction between pregnancy-induced hypertension and history of preterm birth on the risk of small for gestational age. Zhonghua liu xing bing xue za zhi= Zhonghua liuxingbingxue zazhi, 40(7), 786-790. 